\title{
Trophic Status of Lake Akimoto and Physicochemical Comparison with Two Sister Lakes of the Same Age*
}

\author{
Yasuhiro SATOH and Hiroshi Sagisaka
}

\begin{abstract}
The trophic status of Lake Akimoto, which was formed together with sister Lakes Hibara and Onogawa by the volcanic eruption of Mt. Bandai about 100 years ago, is judged to be on the boundary between oligo- and mesotrophic based on some physicochemical parameters. This trophic status is similar to that of Lake Hibara, while Lake Onogawa is on the boundary between meso- and eutrophic. The difference in maximum depth $(33,31$ and $21 \mathrm{~m}$ for Lakes Akimoto, Hibara and Onogawa, respectively) probably caused these trophic differences, which have resulted in some limnological differences among the lakes. Apparent hypolimnetic ammonia regeneration is 6 14 times greater in Lake Onogawa than in Lakes Akimoto and Hibara. Hypolimnetic dissolved oxygen was not exhausted in Lakes Akimoto and Hibara, while an anoxic condition prevailed for two and a half months in Lake Onogawa. Hypolimnetic nitrate was not depleted by nitrate reduction in Lakes Akimoto and Hibara, while it was completely exhausted for three months in Lake Onogawa. Apparent nitrification is indicated from the depth-time diagrams of nitrate in Lakes Akimoto and Hibara, which is not the case in Lake Onogawa.

These three lakes are peculiar in that their lake histories are clear, they have the same age and they lie in a similar environment, but their trophic status is different. Thus, these lakes serve as good fields for comparative studies of many aspects of limnology.
\end{abstract}

Key words : dammed lakes, limnological comparison, seasonal changes, sister lakes

\section{INTRODUCTION}

The summit of volcanic Mt. Bandai in Fukushima Prefecture, Japan, (1.7 $\mathrm{km}^{3}$ in volume) was blown away during the eruption of the volcano in 1888, resulting in large scale mudflows (Murayama, 1973). These mudflows dammed the valleys of many rivers on the Urabandai Plateau and formed some lake basins including Lakes Hibara $\left(37^{\circ} 41^{\prime} \mathrm{N}, 140^{\circ} 03^{\prime} \mathrm{E}\right)$, Onogawa $\left(37^{\circ}\right.$ $\left.40^{\prime} \mathrm{N}, 140^{\circ} 06^{\prime} \mathrm{E}\right)$ and Akimoto $\left(37^{\circ} 39^{\prime} \mathrm{N}, 140^{\circ} 08^{\prime} \mathrm{E}\right)$. At the same time, a large number of depressions on the mudflows formed smaller lake basins.

\footnotetext{
* Contribution No. 21, from Urabandai Limnological Station, Yamagata University.
} 
The surface areas of Lakes Akimoto, Hibara and Onogawa are much greater than those of any other lakes simultaneously formed. These three lakes are connected by a river. Ranked in descending order of altitude, they are Lake Hibara, Lake Onogawa and Lake Akimoto (Fig. 1). The morphology of these lakes is summarized in Table 1. Their surface area and volume in descending order is Lake Hibara, Lake Akimoto and Lake Onogawa. The maximum water depth in descending order is Lake Akimoto, Lake Hibara and Lake Onogawa.

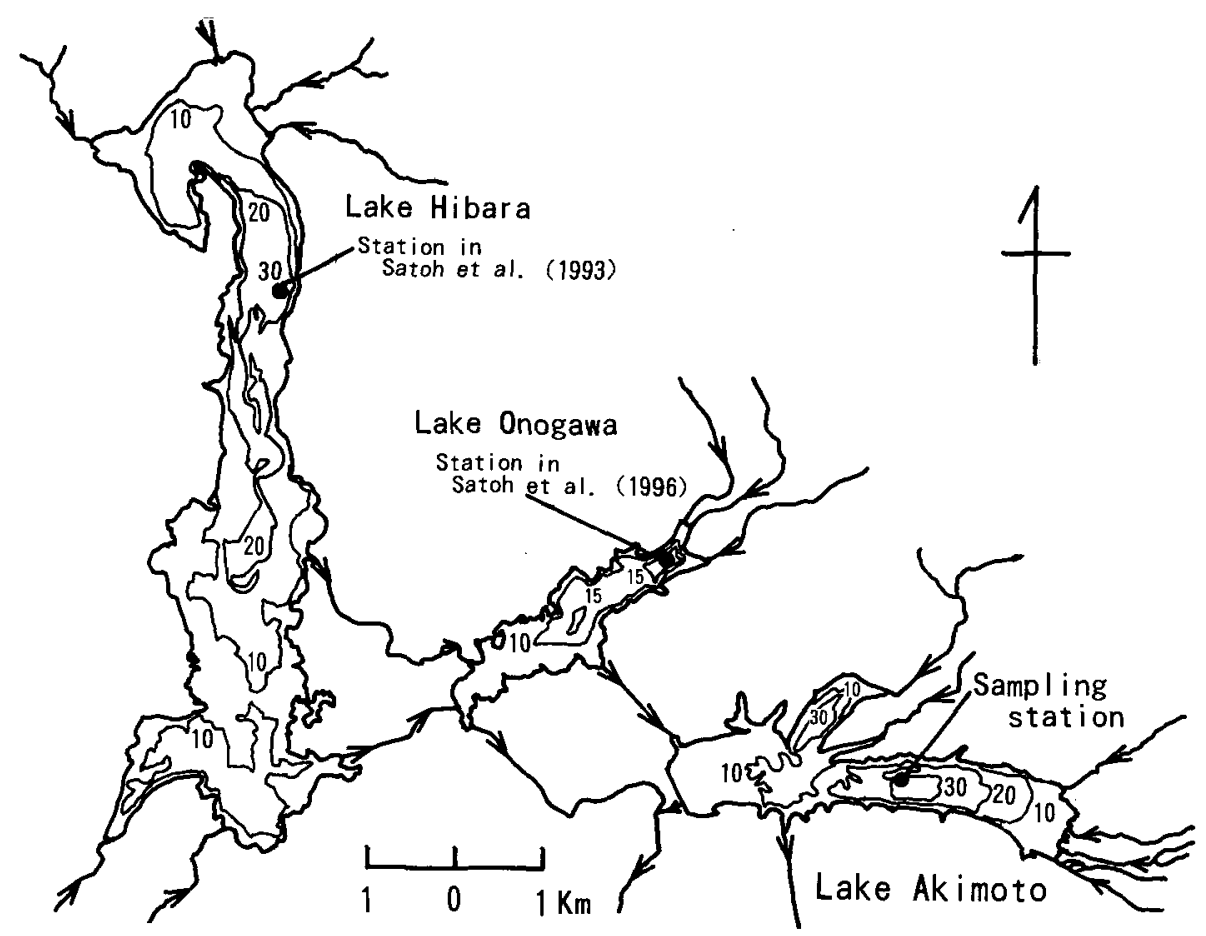

Fig. 1. Map showing the sampling station.

Table 1. Morphology of basins of Lakes Hibara, Onogawa and Akimoto (HORIE, 1962).

\begin{tabular}{lccc}
\hline Lakes & Hibara & Onogawa & Akimoto \\
\hline Altitude $(\mathrm{m})$ & 819 & 794 & 725 \\
Surface area $\left(\mathrm{km}^{2}\right)$ & 10.83 & 1.4 & 3.9 \\
Water volume $\left(\mathrm{km}^{3}\right)$ & 0.13 & 0.014 & 0.05 \\
Maximum depth $(\mathrm{m})$ & 31 & 21 & 33 \\
Mean depth $(\mathrm{m})$ & 12 & 10 & 13 \\
\hline
\end{tabular}

Limnological studies of these lakes have been limited. The earliest study was a measurement of water temperature by TANAKA (1903, 1904). YoshimuRa (1935a, b, c) carried out the first comprehensive limnological 
studies on these lakes. His studies covered morphology, water chemistry and organisms, though he sampled only in July and August. Subsequent studies focused principally on plankton (KoKUBO and KAWAMURA, 1941, WATANABE et al., 1973) and benthos (KITAGAWA, 1974). Some depth profiles for physicochemical parameters such as water temperature, transparency, dissolved oxygen and $\mathrm{pH}$ are available in their studies. However, these authors collected samples only once or twice, mainly in summer. Essentially, seasonal data on any limnological aspect of these lakes were not available until SATOH et al. $(1993,1996)$ measured some physicochemical parameters from spring to early winter and discussed the trophic status of Lakes Hibara and Onogawa. Lake Akimoto still lacks this kind of seasonal data.

The purpose of this study is as follows : 1) to present some depth-time profiles for physicochemical parameters of Lake Akimoto measured from spring to early winter in 1994 ; and 2) to compare the results of the present study with those of Lake Hibara (SАTOH et al., 1993) and Lake Onogawa (SATOH et al., 1996) to clarify the physicochemical differences among these three sister lakes.

\section{MATERIALS AND METHODS}

Water samples from Lake Akimoto were collected every 3 weeks from April to December 1994 with a 6 liter Van Dorn water sampler from the station shown in Fig. 1. Water samples usually from $4.5 \mathrm{~m}$ depth intervals were kept in clean 4-liter polyethylene bottles which were stored in heat insulating boxes and transported to a laboratory at Yamagata University. The water samples were filtered through pre-ignited Whatman GF/F glass fiber filters (nominal porosity, $0.7 \mu \mathrm{m}$ ) under reduced pressure $(<100 \mathrm{~mm}$ $\mathrm{Hg}$ ). The filtration was started within $5 \mathrm{hr}$ and finished within $8 \mathrm{hr}$ after sample collection. Aliquots of the filtrates were kept in clean polyethylene bottles and stored frozen prior to chemical analyses for dissolved components. Aliquots of the unfiltered water samples were also kept frozen until analysed for total nitrogen and total phosphorus. Suspended substances in l-liter water samples were collected on Whatman GF/F glass fiber filters for Chl. $a$ analysis. Measured physicochemical parameters and the methods used are shown in Table 2.

\section{RESULTS}

Lake Akimoto is a dimictic lake like Lakes Hibara and Onogawa. It is covered with ice from January or February to March or April. On the first sampling date, 28 April, a weak gradient of water temperature existed already: the surface water temperature was $9.3{ }^{\circ} \mathrm{C}$ and the bottom water temperature, $3.9^{\circ} \mathrm{C}$ (Fig. 2). Stratification was well developed in early June and continued to the end of September. The maximum water temperature in 1994 was $26.6{ }^{\circ} \mathrm{C}$ at the surface on 10 August. Based on the depth-time diagram, the $9^{\circ} \mathrm{C}$ isotherm line separates the hypolimnion from its overlying 
Table 2. Measured parameters and methods used.

\begin{tabular}{ll}
\hline Parameter & Method \\
\hline Water temperature & Thermistor thermometer \\
Transparency & Secchi disk \\
Dissolved Oxygen & Winkler method \\
Chl. $a$ & SCOR/UNESCO (1966) after 90\% acetone extraction \\
Total nitrogen & UV measurement after persulfate digestion (OTSUKI, 1981) \\
Total phosphorus & Molybdate blue method after persulfate digestion (MENZEL \\
& and CoRWIN, 1965) \\
Ammonia & Phenol hypochlorite method (SÕLORZANO, 1969) \\
Nitrate & Cadmium reduction method (STRICKLAND and PARSONS, \\
& 1972). Separately determined nitrite was subtracted. \\
Reactive phosphorus & Molybdate blue method (STRICKLAND and PARSONS, 1972) \\
\hline
\end{tabular}

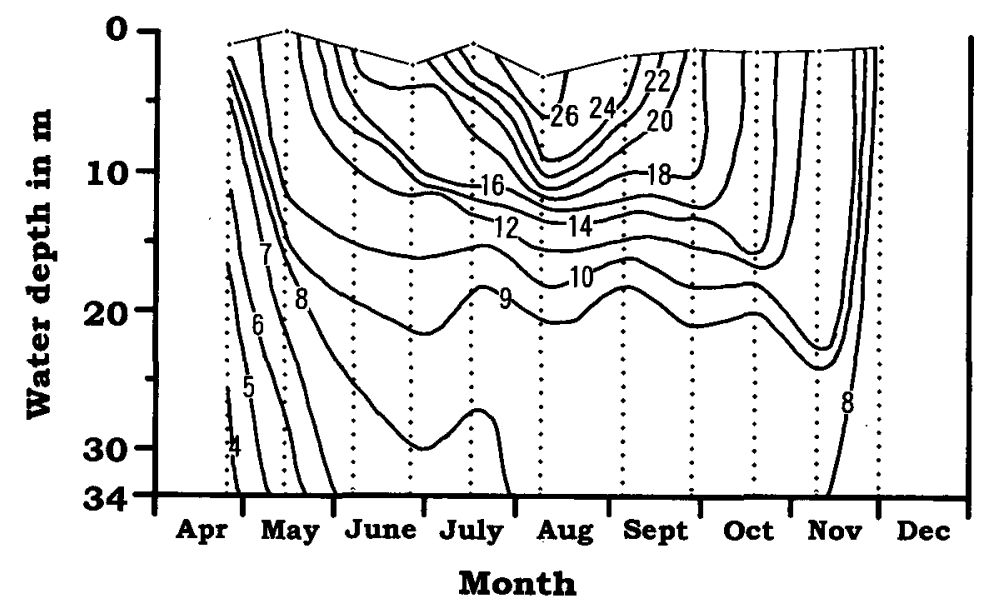

Fig. 2. Depth-time diagram of water temperature of Lake Akimoto in ${ }^{\circ} \mathrm{C}$ in 1994.

metalimnion. Thus, the bottom of the metalimnion lay about $17 \mathrm{~m}$ below the surface. This depth is about $2 \mathrm{~m}$ deeper than those of Lakes Hibara (SATOH et al. 1993) and Onogawa (SAToH et al. 1996). As has been pointed out by YoshimuRa (1930), strong winds very often blow over Lake Akimoto from east to west, the direction of the maximum length of this lake. Water mixing caused by these winds probably resulted in a deeper metalimnion in Lake Akimoto. The hypolimnetic water temperature ranged from $7 \sim 9{ }^{\circ} \mathrm{C}$ before August and from $8 \sim 9{ }^{\circ} \mathrm{C}$ after August. Water circulated partially in mid-October and completely in December.

The transparency changed between $2.7 \mathrm{~m}$ on 28 June and $6.2 \mathrm{~m}$ on 6 September (Table 3). When the period from 9 June to 29 September is taken as the summer stratification period, the average transparency is $4.6 \mathrm{~m}$. On the other hand, the average transparency during both the vernal (28 April and 17 May) and autumnal (20 October through 1 December) circulation periods is $3.3 \mathrm{~m}$. Though the minimum for the period studied was found 
Table 3. Transparency in $\mathrm{m}$ of Lake Akimoto in 1994.

\begin{tabular}{lccc}
\hline Date & Transparency & Date & Transparency \\
\hline 28 April & 3.8 & 6 September & 6.2 \\
17 May & 3.0 & 29 September & 5.0 \\
9 June & 4.3 & 20 October & 2.8 \\
28 June & 2.7 & 10 November & 3.6 \\
18 July & 3.7 & 1 December & 3.5 \\
10 August & 5.4 & & \\
\hline Stratification period & $4.6 \pm 1.3$ & & \\
\hline Circulation period & $3.3 \pm 0.4$ & & \\
\hline
\end{tabular}

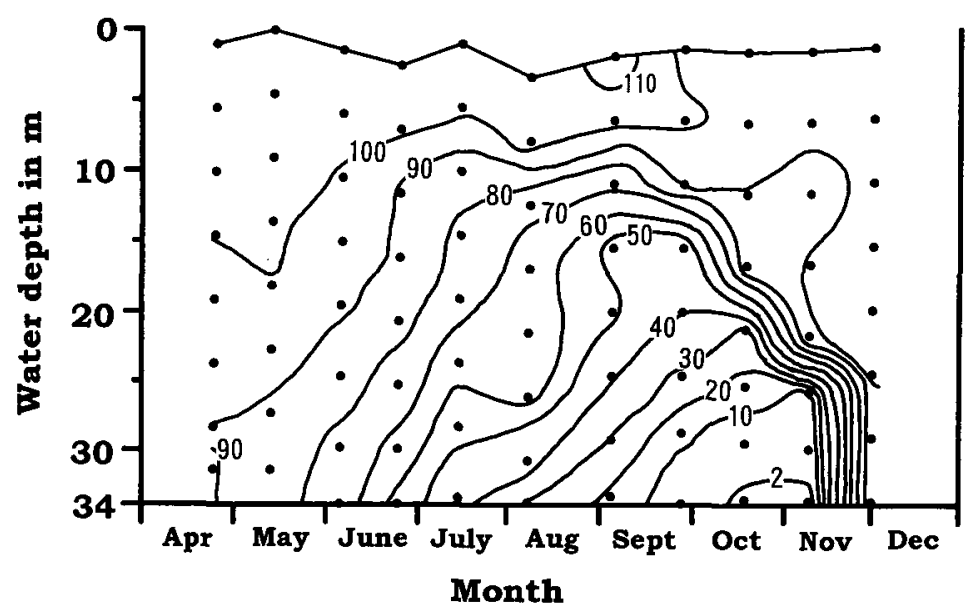

Fig. 3. Depth-time diagram of $\%$ of dissolved oxygen in Lake Akimoto in 1994.

in the stratification period, the average transparency was greater in the stratification period than in the circulation period.

Dissolved oxygen ranged from $1.3 \%\left(0.14 \mathrm{mg} \mathrm{l}^{-1}\right)$ at a depth of $32 \mathrm{~m}$ on 10 November to $115 \%\left(8.44 \mathrm{mg} \mathrm{l}^{-1}\right)$ at the surface on 6 September (Fig. 3). Dissolved oxygen in a layer of the upper $12 \mathrm{~m}$ was slightly oversaturated from April to mid-May. This slightly over saturated layer became shallower (upper $4 \sim 5 \mathrm{~m}$ ) coincident with the development of the summer stratification, and disappeared when autumnal partial circulation began. The metalimnetic dissolved oxygen decreased with time from more than $90 \%$ in early June to $40 \sim 50 \%$ in September. The hypolimnetic dissolved oxygen also decreased with time from about $90 \%$ in April to less than $2 \%$ just $60 \mathrm{~cm}$ above the water-sediment interface from October to early November. Thus, trace amounts of dissolved oxygen still remained in the hypolimnion until the complete autumnal water mixing started.

Ammonia accumulated slightly in the hypolimnion in spring (Fig. 4). The maximum concentration there was $2.83 \mu \mathrm{g}$ atom $\mathrm{N}^{-1}$ at a depth of $31 \mathrm{~m}$ on 17 May. After that ammonia in the lower hypolimnion decreased to a level 


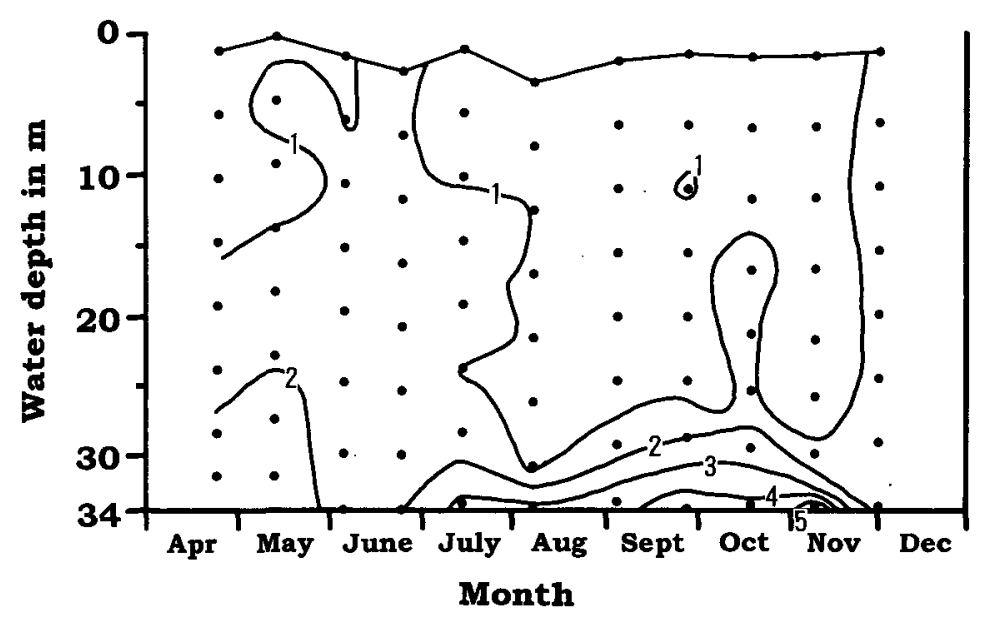

Fig. 4. Depth-time diagram of ammonia in Lake Akimoto in $\mu \mathrm{g}$ atom $\mathrm{N}^{-1}$ in 1994.

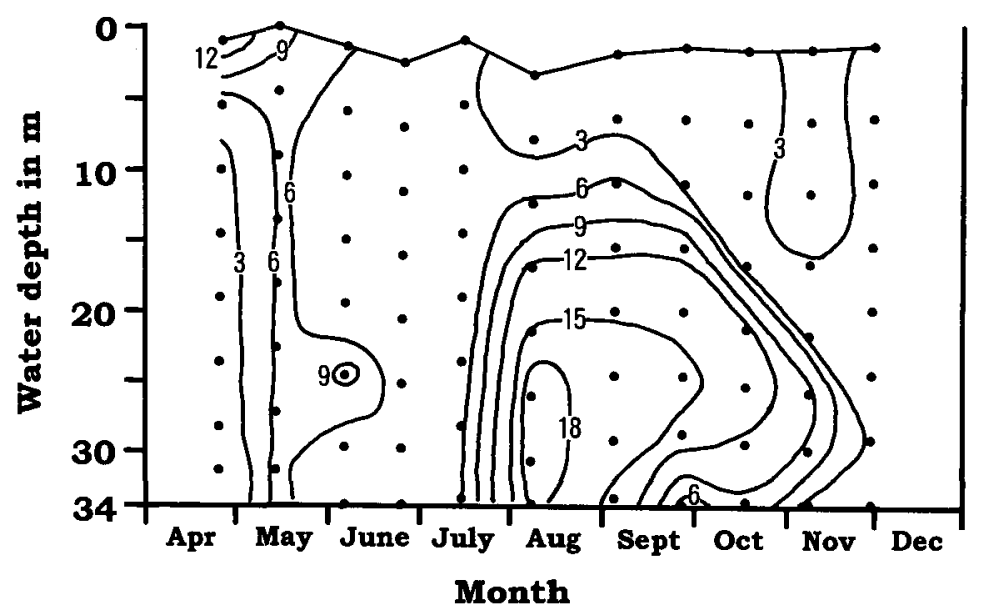

Fig. 5. Depth-time diagram of nitrate in Lake Akimoto in $\mu \mathrm{g}$ atom $\mathrm{N}$ $\mathrm{l}^{-1}$ in 1994.

of about $1.5 \mu \mathrm{g}$ atom $\mathrm{N}^{-1}$. This low level remained for about one month, followed by an evident accumulation starting in late June, and forming a high concentration layer of more than $2 \mu \mathrm{g}$ atom $\mathrm{N}^{-1}$. The thickness of the layer having more than $2 \mu \mathrm{g}$ atom $\mathrm{N}^{-1}$ increased with time, and reached the maximum thickness of about $6 \mathrm{~m}$ from the lake bottom in mid-October. This layer disappeared when water circulated completely in December. An annual maximum of $5.62 \mu \mathrm{g}$ atom $\mathrm{N} \mathrm{l}^{-1}$ was recorded about $60 \mathrm{~cm}$ above the water-sediment interface on 10 November.

Nitrate decreased with depth from 14.1 to $1.03 \mu \mathrm{g}$ atom $\mathrm{N}^{-1}$ in April and distributed essentially uniformly throughout the water column in May at a level of around $7 \mu \mathrm{g}$ atom $\mathrm{N}^{-1}$ except for a maximum of $10.0 \mu \mathrm{g}$ atom $\mathrm{N} \mathrm{I}^{-1}$ 
at the surface (Fig. 5). Nitrate was at a relatively low level in the whole water column between 3 and $6 \mu \mathrm{g}$ atom $\mathrm{N}^{-1}$ from June to mid-July except for a maximum that formed at $23 \mathrm{~m}$ on 9 June. Hypolimnetic nitrate suddenly began to increase from mid-July, and reached the annual maximum of $19.1 \mu \mathrm{g}$ atom $\mathrm{N}^{-1}$ at $27 \mathrm{~m}$ on 10 August, suggesting nitrification. After that it gradually decreased, indicating nitrate reduction, and then it became uniform from the surface to the bottom at a level of around $2.5 \mu \mathrm{g}$ atom $\mathrm{N} \mathrm{l}^{-1}$ coincident with the autumnal water circulation.

In general, total nitrogen increased with depth except during the autumnal circulation period (Fig. 6). However, the concentration difference between the surface and the bottom was small in spring. That difference became clearer from July, when an evident high concentration layer of more than 25 $\mu \mathrm{g}$ atom $\mathrm{N} \mathrm{l}^{-1}$ was formed above the water-sediment interface. The isopleth of $25 \mu \mathrm{g}$ atom $\mathrm{N}^{-1}$ lay at about $27 \mathrm{~m}$ from the surface in mid-July. It moved upward with time, and lay at about $18 \mathrm{~m}$ from the surface from September to mid-October. After the start of partial water circulation, the isopleth of $25 \mu \mathrm{g}$ atom $\mathrm{N}^{-1}$ moved downward with time. With the beginning of complete water circulation, total nitrogen distributed uniformly in the whole water column at a level between 5 and $10 \mu \mathrm{g}$ atom N ${ }^{-1}$. Annual maximum was $60.0 \mu \mathrm{g}$ atom $\mathrm{N}^{-1}$ at $31.7 \mathrm{~m}(60 \mathrm{~cm}$ above the lake bottom) on 10 November.

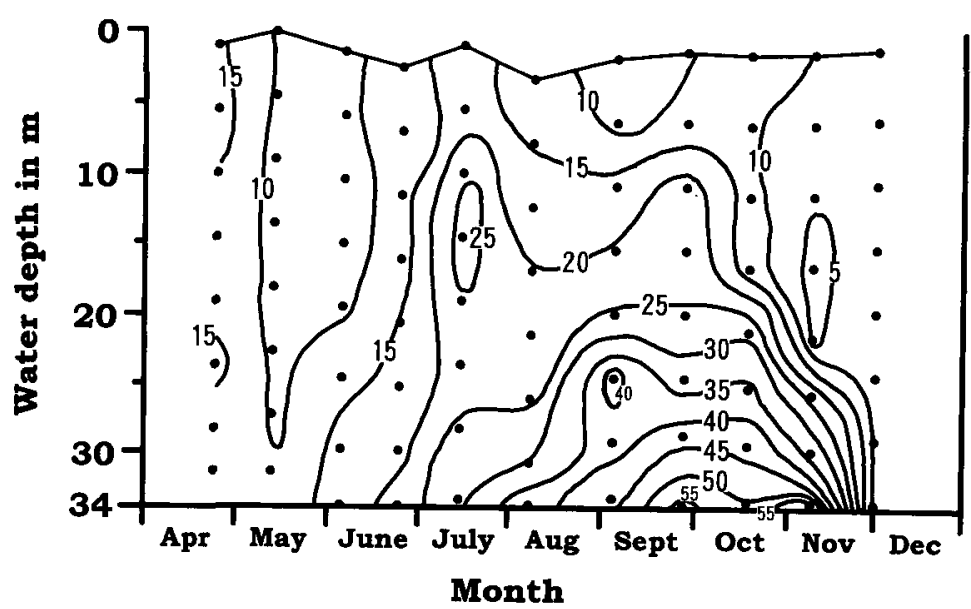

Fig. 6. Depth-time diagram of total nitrogen in Lake Akimoto in $\mu \mathrm{g}$ atom $\mathrm{N} \mathrm{l}^{-1}$ in 1994.

The concentration of reactive phosphorus ranged from less than 0.10 to $0.22 \mu \mathrm{g}$ atom $\mathrm{P} \mathrm{l}^{-1}$ (Fig. 7). The annual maximum was observed in the epilimnion on 1 December. The concentration of total phosphorus ranged from 0.18 to $0.78 \mu \mathrm{g}$ atom $\mathrm{P} \mathrm{l}^{-1}$ (Fig. 8). This annual maximum was recorded at the surface on 17 May when Chl. $a$ reached a maximum (Fig. 9). Chl. $a$ reached the annual maximum of $8.9 \mu \mathrm{g} \mathrm{l}^{-1}$ at the surface on 20 
October. However, total phosphorus did not show a maximum at this time. The annual maximum of Chl. $a$ in this lake is about $40 \%$ and $70 \sim 80 \%$ lower, respectively, than those in Lake Hibara $\left(15 \mu \mathrm{g} \mathrm{l}^{-1} \mathrm{SATOH}\right.$ et al., 1993) and Lake Onogawa $\left(33 \mu \mathrm{g} \mathrm{l}^{-1}\right.$ in 1993 and $48 \mu \mathrm{g} \mathrm{l}^{-1}$ in 1994 in SATOH et al,. 1996).

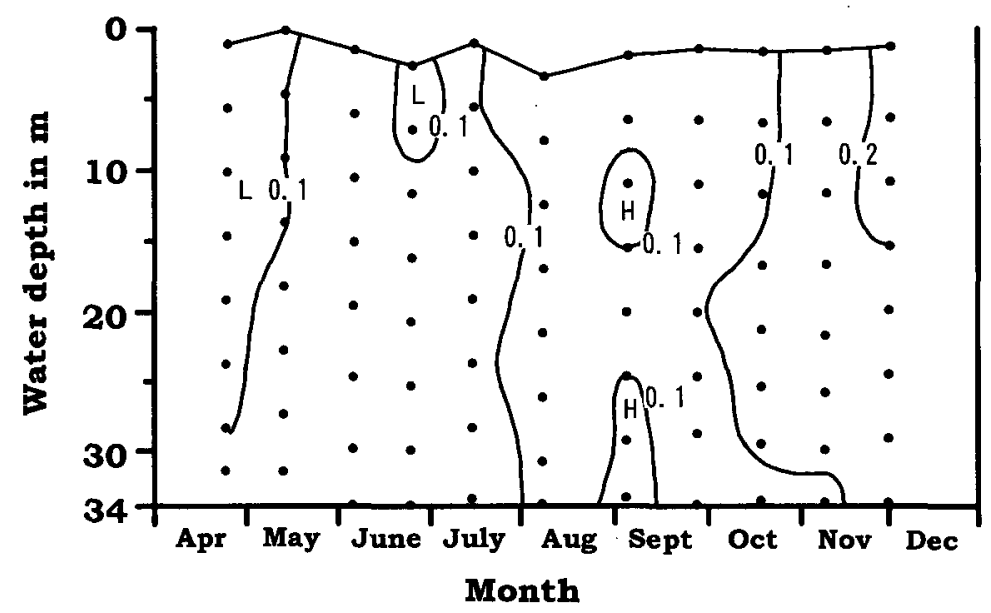

Fig. 7. Depth-time diagram of reactive phosphorus in Lake Akimoto in $\mu \mathrm{g}$ atom $\mathrm{P} \mathrm{I}^{-1}$ in 1994.

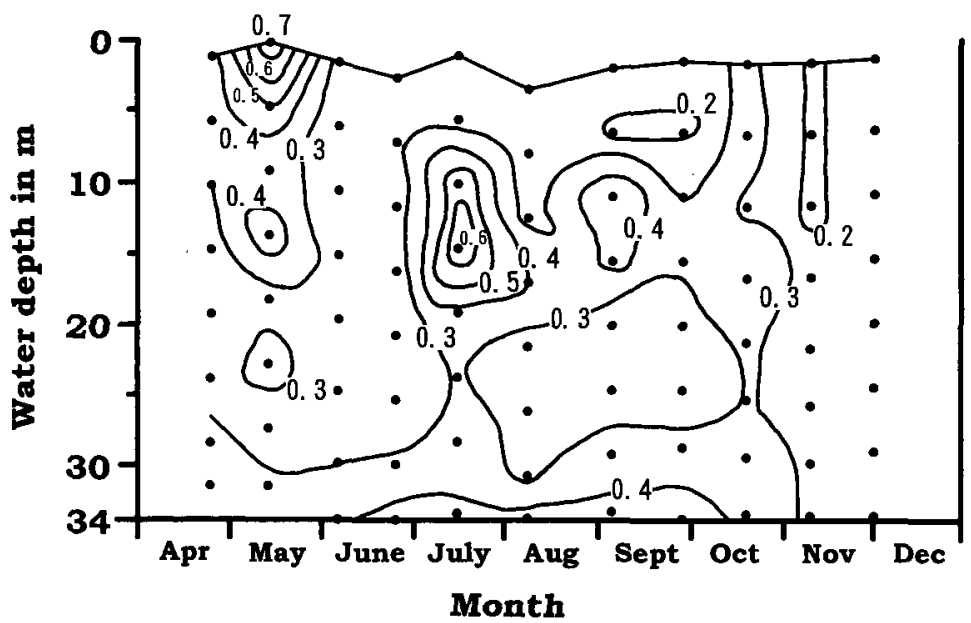

Fig. 8. Depth-time diagram of total phosphorus in Lake Akimoto in $\mu \mathrm{g}$ atom $\mathrm{P} \mathrm{l}^{-1}$ in 1994. 


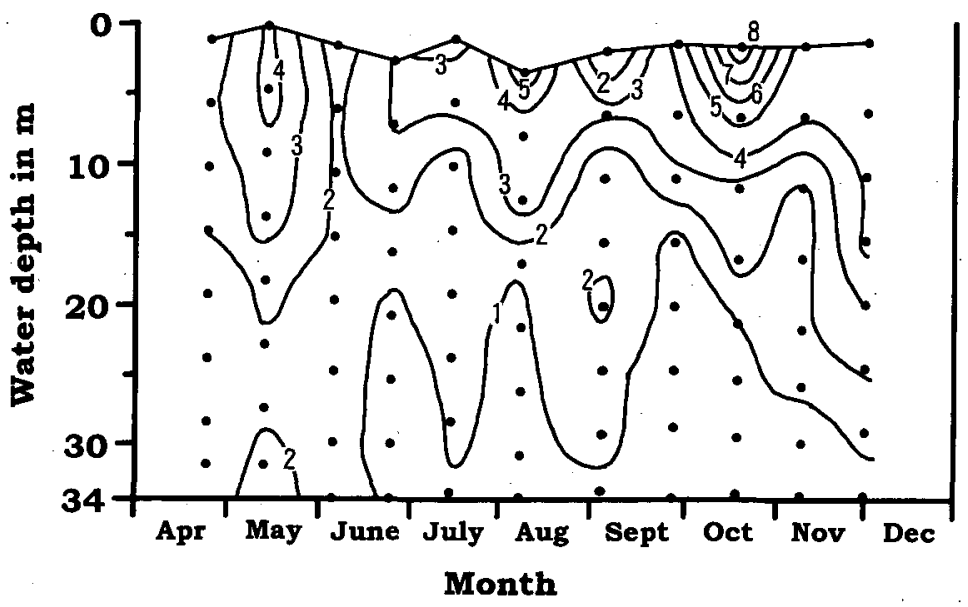

Fig. 9. Depth-time diagram of Chl. $a$ in Lake Akimoto in $\mu \mathrm{g} \mathrm{l}^{-1}$ in 1994.

\section{DISCUSSION}

The trophic status of Lake Akimoto is judged to be on the boundary between oligo- and mesotrophic. The circulation period is the proper season to study the trophic status of lakes based on material concentrations (SAKAMOTO, 1962). The mean concentrations of Chl. $a$, total nitrogen and total phosphorus were calculated from the samples of the upper three layers $(0,4.5$ and $9 \mathrm{~m})$ in April, May (vernal circulation), and October through December (autumnal circulation). A mean transparency for the same period is given in Table 3. By using the criteria of FoRSBERG and RYDING (1980), the concentrations of Chl. a, total nitrogen, total phosphorus and transparency indicate that the lake should be meso-, oligo-, oligo- and mesotrophic, respectively (Table 4).

Table 4. Trophic status indicated by Chl. $a\left(\mu \mathrm{g} \mathrm{l}^{-1}\right)$, total nitrogen $(\mu \mathrm{g}$ atom $\mathrm{N}^{-1}$ ), total phosphorus ( $\mu \mathrm{g}$ atom $\mathrm{P}^{-1}$ ) and transparency (m) based on FORSBERG and RYDING's criteria (1980).

\begin{tabular}{lccc}
\hline & Average & Critical value & Judgment \\
\hline Chl. $a$ & $4.1 \pm 1.7$ & $3 \sim 7$ & mesotrophic \\
Total nitrogen & $11 \pm 3$ & $<28$ & oligotrophic \\
Total phosphorus & $0.33 \pm 0.15$ & $<0.48$ & oligotrophic \\
Transparency & $3.3 \pm 0.4$ & $2.5 \sim 4.0$ & mesotrophic \\
\hline
\end{tabular}

Previously, two depth profiles of dissolved oxygen in Lake Akimoto were available (Yoshimura, 1931, Kitagawa, 1974 in Fig. 10). Yoshimura measured dissolved oxygen on 10 August 1930, and we determined it on the same date 64 years later. KiTAGAWA collected samples for dissolved oxygen on 29 June 1973, and we collected them 21 years and one day later. The 
depth profiles of KITAGAWA's study and ours are essentially the same. On the other hand, YosHimura's profile differed significantly from ours. The present profile shows a more eutrophic character, i.e., dissolved oxygen is higher in the epilimnion and lower in the meta- and hypolimnion. However, since year-to-year differences in the distribution of dissolved oxygen are sometimes very large, it may not be proper to discuss changes in the trophic status of the lake from these results.
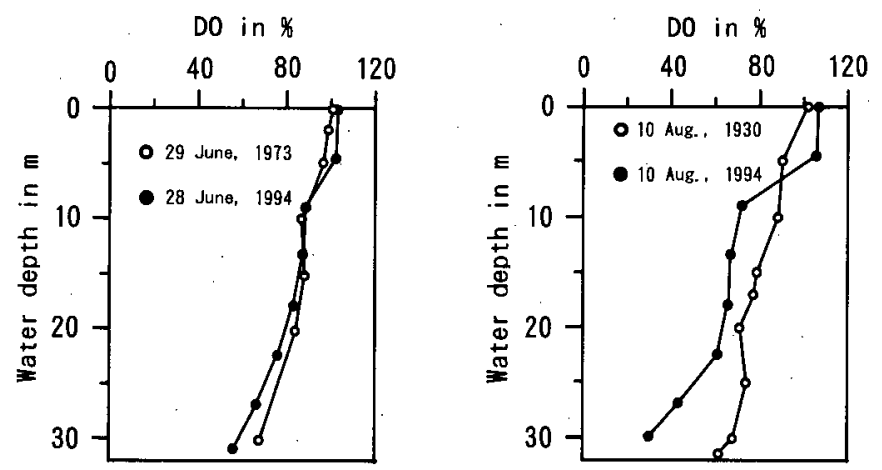

Fig. 10. Depth profiles for \% of dissolved oxygen. Upper; 29 June 1973 (open circle) from KitaGawa (1974) and 28 June 1994 (solid circle) from this study. Lower ; 10 August 1930 (open circle) from YoshrmuRA (1931) and 10 August 1994 (solid circle) from this study.

The trophic status of a sister lake, Lake Hibara, is on the same level as that of Lake Akimoto, i.e., it is on the boundary between oligo- and mesotrophic ( ААтон et al., 1993), while another sister lake, Lake Onogawa, is more productive, being on the boundary between meso- and eutrophic (SАтон et al., 1996). It is interesting to note that the lakes of the same age lying in a similar environment have reached a different trophic status in about the last 100 years. The shallower maximum water depth of Lake Onogawa has probably resulted in higher productivity, as has been mentioned in SАTоH et al. (1996).

The trophic differences resulted in some limnological differences between Lakes Akimoto and Hibara, and Lake Onogawa. 1) Apparent hypolimnetic ammonia regeneration suggested by the ammonia accumulation is about 6 14 times greater in Lake Onogawa than in Lakes Akimoto and Hibara (compare maxima in Table 5). 2) Anoxic hypolimnion appeared for about two and a half months in Lake Onogawa (SATOH et al., 1996), whereas trace amounts of dissolved oxygen remained in the hypolimnia even at the final stages of the summer stratification in Lakes Akimoto and Hibara (Fig. 3 and SATOH et al., 1993). 3) Based on the depth-time diagrams for nitrate, nitrate reduction may have occurred in all three sister lakes (Fig. 5 and SАтоH et al., 1993, 1996). However, nitrate did not completely disappear 
Table 5. Comparison of some limnological features of sister Lakes Akimoto Hibara and Onogawa.

\begin{tabular}{|c|c|c|c|}
\hline & Lake Akimoto & Lake Hibara & Lake Onogawa \\
\hline Trophic status & $\begin{array}{l}\text { oligo- to } \\
\text { mesotrophic }\end{array}$ & $\begin{array}{l}\text { oligo- to } \\
\text { mesotrophic }\end{array}$ & $\begin{array}{l}\text { meso- to } \\
\text { eutrophic }\end{array}$ \\
\hline Transparency (m) & $\begin{array}{l}4.6 \text { (stratif.) } \\
3.3 \text { (circula.) }\end{array}$ & $\begin{array}{l}4.9 \text { (stratif.) } \\
3.2 \text { (circula.) }\end{array}$ & $\begin{array}{ll}5.4 & \text { (stratif.) } \\
5.2 & \text { (stratif.) } \\
3.1 & \text { (circula.) } \\
3.4 & \text { (circula.) }\end{array}$ \\
\hline $\begin{array}{l}\text { Hypolimnetic dissolved } \\
\text { oxygen }\end{array}$ & trace & trace & $\begin{array}{l}\text { exhausted } \\
\text { exhausted }\end{array}$ \\
\hline $\begin{array}{l}\text { Range of ammonia ( } \mu \mathrm{g} \text { atom } \\
\mathrm{N} \mathrm{l}^{-1} \text { ) }\end{array}$ & $0.0 \sim 5.6$ & $0.3 \sim 11.5$ & $\begin{array}{l}0.2 \sim 64.8 \\
0.2 \sim 80.1 \\
\end{array}$ \\
\hline $\begin{array}{l}\text { Range of nitrate ( } \mu \mathrm{g} \text { atom } \\
\mathrm{N}^{-1} \text { ) }\end{array}$ & $1.0 \sim 19.1$ & $0.0 \sim 17.5$ & $\begin{array}{l}0.0 \sim 18.7 \\
0.0 \sim 9.1\end{array}$ \\
\hline $\begin{array}{l}\text { Range of total nitrogen }(\mu \mathrm{g} \\
\left.\text { atom } \mathrm{N}^{-1}\right)\end{array}$ & $3.0 \sim 60.0$ & $5.3 \sim 59.8$ & - \\
\hline $\begin{array}{l}\text { Range of reactive } \mathrm{P}(\mu \mathrm{g} \\
\left.\text { atom } \mathrm{P}^{-1}\right)\end{array}$ & $<0.05 \sim 0.22$ & $0.07 \sim 0.47$ & $\begin{array}{l}<0.05 \sim 0.46 \\
<0.05 \sim 0.37\end{array}$ \\
\hline $\begin{array}{l}\text { Range of total } \mathrm{P}(\mu \mathrm{g} \text { atom } \mathrm{P} \\
\left.1^{-1}\right)\end{array}$ & $0.18 \sim 0.78$ & $0.16 \sim 0.97$ & $\begin{array}{l}0.19 \sim 0.79 \\
0.11 \sim 0.94\end{array}$ \\
\hline Range of Chl. $a\left(\mu \mathrm{g} \mathrm{l}^{-1}\right)$ & $0.4 \sim 8.9$ & $0.7 \sim 15.0$ & $\begin{array}{l}0.7 \sim 33.3 \\
0.8 \sim 48.3\end{array}$ \\
\hline
\end{tabular}

1) Physicochemical data of Lake Hibara are from $\mathrm{S}_{\mathrm{ATOH}}$ et al. (1993).

2) Physicochemical data of Lake Onogawa are from $\mathrm{S}_{\mathrm{ATOH}}$ et al. (1996). The upper row shows the results in 1993 and the lower row in 1994.

3) The abbreviations in the row of transparency (stratif. and circula.) signify stratification period and circulation period, respectively.

in Lakes Akimoto and Hibara ; the hypolimnetic nitrate remained at a level of $2.46 \mu \mathrm{g}$ atom $\mathrm{N}^{-1}$ in Lake Akimoto and $0.13 \mu \mathrm{g}$ atom $\mathrm{N}^{-1}$ in Lake Hibara at the final stage of the summer stratification. On the other hand, it disappeared for almost three months in the $5 \mathrm{~m}$ thickness above the watersediment interface in Lake Onogawa (SATOH et al., 1996). 4) The balance among ammonification, nitrification and nitrate reduction differs in these three lakes. Apparent nitrification is indicated from the depth-time diagrams of nitrate in Lake Akimoto (Fig. 5) and Lake Hibara (SАTоH et al., 1993), while it is not indicated in Lake Onogawa (SАTOH et al., 1996). Hypolimnetic ammonia of Lake Akimoto increased slightly from late June prior to the sharp increase in nitrate (Figs. 4, 5). However, the level of accumulated ammonia was too insufficient to explain the amount of nitrate formed. In the period between 18 July and 10 August, ammonia at 27 and $31 \mathrm{~m}$ decreased from 1.44 to $0.92 \mu \mathrm{g}$ atom $\mathrm{N} \mathrm{l}^{-1}$ and from 3.12 to $3.03 \mu \mathrm{g}$ atom $\mathrm{N} \mathrm{l}^{-1}$, respectively, whereas nitrate there increased from 4.47 to 19.1 $\mu \mathrm{g}$ atom $\mathrm{N}^{-1}$ and from 3.95 to $19.1 \mu \mathrm{g}$ atom $\mathrm{N}^{-1}$, respectively. During the active nitrification, ammonification should also have been active and formed 
ammonia, which should have been immediately oxidized to nitrate. These situations differ from those found in Lakes Hibara (SATOH et al., 1993) and Onogawa (SАTOH et al., 1996). Substantial amounts of ammonia accumulated in the hypolimnion prior to the sudden nitrification in Lake Hibara (SATOH et al., 1993). Using the data of SATOH et al. (1993), the accumulated ammonia can account for $34 \%, 58 \%$ and $88 \%$ of nitrate formed at $15 \mathrm{~m}$, $20 \mathrm{~m}$ and $25 \mathrm{~m}$ depths, respectively, in the early stage of nitrification in Lake Hibara. In Lake Onogawa, hypolimnetic ammonia gradually increased from spring to autumn, while at the same time nitrate gradually decreased. From the mass balance based on these depth-time profiles, apparent nitrification was not demonstrated in Lake Onogawa, though it might have occurred ( $\mathrm{SATOH}$ et al., 1996). These facts indicate that the balance among ammonification, nitrification and nitrate reduction differs in these three lakes.

Among the great number of the Japanese lakes, these three are peculiar in that their lake histories are clear, they have the same age, and they lie in a similar environment, but their trophic status is different. Thus, these lakes serve as good fields for comparative studies of many aspects of limnology.

\section{ACKNOWLEDGMENTS}

We are grateful to Dr. R. JoRDAN for his valuable comments on an earlier draft of this paper, and to the many students of our laboratory who helped with the sample collection and chemical analyses.

\section{REFERENCES}

ForsBerg, C. and S-O RYding (1980): Eutrophication parameters and trophic state indices in 30 Swedish waste-receiving lakes. Arch. Hydrobiol., 89 : 189 $-207$.

HoRIE, S. (1962) : Morphometric features and the classification of all the lakes in Japan. Mem. Coll. Sci. Univ. Kyoto (B), $28: 53-71$.

KITAGAWA, N. (1974) : Studies on the bottom fauna of seven lakes of North Japan (in Japanese). Jpn. J. Limnol., $35:$ 162-172.

Kokubo, S. and T. Kawamura (1941) : Plankton and water chemistry of Lake Akimoto and Lake Hibara (in Japanese). Seitaigaku Kenkyu, 7 : 189-195.

Menzel, D. W. and N. CoRwin (1965) : The measurement of total phosphorus in seawater based on the liberation of organically bound fraction by persulfate oxidation. Limnol. Oceanogr., $10: 280-282$.

Murayama, I. (1973): Volcanic Activity and Topography (in Japanese). Taimeido Publishing.

OTsUKI, A. (1981) : Use of ultraviolet spectrophotometric determination of total nitrogen in environmental water samples using alkaline persulfate digestion (in Japanese). Bunseki Kagaku, $30: 688-689$.

SCOR/UNESCO (1966) : Determination of Photosynthetic Pigment in Seawater. UNESCO Publication Center, New York. 
SaKamoto, M. (1962) : Primary production and trophic degree of lakes (in Japanese). Jpn. J. Limnol., $23: 73-85$.

Satoh, Y., N. Koide, S. OAsa, I. Suzuki and T. Suzuki (1993) : Trophic state and hypolimnetic nitrogen metabolism of Lake Hibara. Jpn. J. Limnol., 54 : 4958.

Satoh, Y., S. Nakamura, K. Katoh and H. Sagisaka (1996) : Distribution of some physicochemical parameters and trophic status of Lake Onogawa. Jpn. J. Limnol., 57 : 145-152.

SolOrzano, L. (1969) : Determination of ammonia in natural waters by the phenolhypochlorite method. Limnol. Oceanogr., 14: 799-801.

Strickland J. D. H. and T. R. Parsons (1972): A Practical Handbook of Seawater Analysis (2nd ed.). Bull. Fish. Res. Bd. Canada, $197: 1-310$.

TANAKA, A. (1903) : Lakes in the vicinity of Volcano Bandai (in Japanese). Chigaku-Zasshi 176 : 631-636.

TANAKA, A. (1904) : Lakes in the vicinity of Volcano Bandai (in Japanese). Chigaku-Zasshi $181: 28-32$.

Watanabe, T., K. Mashiko and H. Kamijo (1973) : Water chemistry and plankton of Lakes Hibara, Onogawa, Akimoto and Sohara on the Bandai Plateau (in Japanese). Basic Studies on the Eutrophication of Inland Waters No. 2., 2628.

Yoshimura, S. (1930) : A preliminary report on water temperature and dissolved oxygen in main- and sub-basins of Lake Akimoto, Fukushima Prefecture (in Japanese). Chikyu $14: 330-343$.

Yoshimura, S. (1931) : Water Temperature and dissolved oxygen in several subaqueous basins of Lake Akimoto, Fukushima. Arch. Hydrobiol. 23 : 279283.

Yoshimura, S. (1935a) : Preliminary study on the local limnology of volcanic lakes around Volcano Bandai (1) (in Japanese). Chirigaku Hyoron, 8 : 782802.

Yoshimura, S. (1935b) : Preliminary study on the local limnology of volcanic lakes around Volcano Bandai (2) (in Japanese). Chirigaku Hyoron, 8 : 860880.

Yoshimura, S. (1935c) : Preliminary study on the local limnology of volcanic lakes around Volcano Bandai (3) (in Japanese). Chirigaku Hyoron, 8 : 933976.

Yasuhiro SAтоH : Faculty of Science, Yamagata University, 1-4-12 Koshirakawamachi, Yamagata 990 (佐藤泰哲 : $=990$ 山形市小白川町 1-4-12 山形大学 理学部)

Hiroshi SAGiSAKa : Faculty of Science, Yamagata University, 1-4-12 Koshirakawamachi, Yamagata 990 (勾坂 宙: $=990$ 山形市小白川町 1-4-12 山形大 学理学部)

(Received : 26 February 1997 ; Accepted : 29 July 1997) 


\title{
秋元湖の栄養状態および同一年齢の 2 つの姉妹湖との 物理・化学的比較
}

\author{
佐藤泰哲・勾坂 宙
}

摘 要

秋元湖は檜原湖, 小野川湖同様，1888 年の磐梯山の噴火に伴う泥流によるせき止め湖で ある。全窒素，全リン，クロロフィル，透明度に基づき，秋元湖は貧栄養と中栄養の境界 にあると判断された。この栄養状態は，檜原湖と同じで小野川湖より筫栄養である。恐ら く, 最大水深(秋元湖 $33 \mathrm{~m}$, 檜原湖 $31 \mathrm{~m}$, 小野川湖 $21 \mathrm{~m}$ )の違いが，この 100 年の間に, 栄養状態の違いを生み出したのであろう。

この栄養状態の違いが秋元，檜原湖と小野川湖の間に，いくつかの湖沼学的な相違を生 み出している。即ち，1）深水層における見かけ上のアンモニアの再生は, 小野川湖では秋 元湖, 檜原湖の 6 14 倍である。2) 秋元, 檜原湖では, 深水層の溶存酸素はゼ口にならな いが，小野川湖ではほぼ 2 力月半，嫌気状態となる。3）硝酸塩の時空間分布より，3つの 湖共に硝酸還元は起こっていると判断されるが, 秋元湖, 檜原湖では硝酸還元により深水 層の硝酸塩がゼロになる前に秋の循環が始まる。小野川湖の硝酸塩はほぼ 3 力月間, 完全 になくなる。4）硝酸塩の時空問分布より, 秋元湖と檜原湖では硝化が起こっていると判断 されるが，小野川湖では硝酸塩の時空間分布からは，硝化は示唆されない。アンモ二ア再 生，硝化，硝酸還元活性のバランスが湖により異なると考えられる。

これら 3 つの湖は歴史が明らかで，年齢が同じで，同一環境に存在するが，栄養状態は 賀から中栄養の秋元湖及び檜原湖，中から富栄養の小野川湖と異なる。それ故，様々な観 点からの比較湖沼学的研究のために良い研究対象となろう。 